\title{
The New Rules of Capital Adequacy Basel III from the Perspective of Leasing Companies in Europe and Czech Republic
}

\author{
Martin Svítil \\ Soukromá vysoká škola ekonomická Znojmo \\ Loucká 656/21, 66902 Znojmo, Czechia \\ E-mail: svitil.martin@svse.cz
}

\begin{abstract}
Some significant changes to the Basel III regulatory framework (called Basel IV) will come into effect during the 2022 to 2027 period. In its first part, this article shows the opinion of the European Federation of Leasing Company Associations Leaseurope on Basel IV. In its second part, this paper evaluates the situation of the largest leasing companies on the Czech market using methods of financial analysis.
\end{abstract}

The results of several studies published by Leaseurope clearly show that the risk associated with the provision of liabilities through leasing is significantly lower than the risk calculated by the capital adequacy calculation for Basel rules. For this reason, the Leaseurope federation prepared concrete proposals for changes in the rules so that the regulation better corresponds to the actual risks taken.

The second part of the article analyzes the situation of leasing companies in the Czech Republic in terms of capital, capital adequacy and compliance with Basel rules. It shows the state of the capital adequacy of the largest leasing companies operating on the Czech market using simplified indicators of the ratio of Equity / Balance sheet total and Equity / Receivables. As a complementary indicator, the ratio of Share capital / Balance sheet total is also used. Furthermore, a simplified stress test based on $5 \%$ and $10 \%$ decline in net receivables and coverage of this decline from equity, respectively, was performed.

The results show that leasing companies operating on the Czech market would probably have no problem meeting the considered tightening of capital requirements. Several exceptions are mentioned in the text.

Keywords: leasing, Basel III, capital, regulatory capital

JEL codes: G23, G32, G38

\section{Introduction}

The aim of this article is to evaluate the opinions and the position of leasing companies in Europe and the Czech Republic in relation to the newly prepared rules of Basel III regulatory framework (sometimes called Basel IV), which should enter into force between 2022 and 2027. The proposed new rules raise two 
questions: (i) whether they should be and will be approved and implemented and, if so, (ii) whether financial institutions (here leasing companies) are prepared for them.

This paper also follows and expands last year's work (Svítil 2019), especially in its first part, focusing on the opinion of the European Federation of Leasing Company Associations Leaseurope on the rules of capital adequacy. This section looks for the answer to the first question (i) mentioned above.

In its second part, this article tries to answer the second question (ii) by assessing the situation of the largest leasing companies on the Czech market in terms of capital adequacy and preparedness for the intended new rules using selected methods of financial analysis.

The structure of the text is as follows:

- chapter 2 describes the current situation of leasing financing in Europe and Czech Republic;

- chapter 3 states the methodology and the sources of data used;

- point 4.1 shows the Leaseurope's opinion on the new regulation;

- point 4.2 deals with the capital adequacy of Czech leasing companies using selected indicators of financial analysis;

- chapter 5 provides a summary of the findings and conclusions.

\section{Current Situation of Leasing Financing in Europe and in the Czech Republic}

Leasing financing has long been a common and popular way of acquiring liabilities for businesses throughout Europe, including the Czech Republic.

According to the European Federation of Leasing Company Associations Leaseurope (Leaseurope 2019), its members provided funding of EUR 384,1 billion (of which EUR 14,7 billion in real estate financing) in 2017 for all products provided. Out of this, net leasing financing without related products for 2017 accounted for EUR 291,6 billion (+ 9,93\% compared to 2016), realized through 7,6 million contracts ( $6,8 \%$ versus 2016 ). Thus, the average contracted amount was about $€ 38$ 400. The net leasing portfolio reached EUR 649,2 billion $(+2,5 \%)$.

As Table 1 shows, most of Europe's largest leasing companies are owned by either large banks (the fourth company in the list, a Dutch DLL belonging to the not very well-known Rabobank Group), or by a large automobile manufacturer, such as the German Alphabet, which is part of the BMW Group. Exceptions are, for example, Siemens Financial Services, (Germany), or LeasePlan, owned by a pension funds and investment funds group. 
Table 12017 Leaseurope Ranking of European Leasing Companies

\begin{tabular}{|c|c|c|c|c|}
\hline Rank & Company & Country & $\begin{array}{l}\text { Total new business } \\
\text { within Europe in } \\
2017 \text { (thousands } € \text { ) }\end{array}$ & $\begin{array}{c}\text { Number of new } \\
\text { contracts within } \\
\text { Europe in } 2017\end{array}$ \\
\hline 1. & $\begin{array}{l}\text { Société Générale } \\
\text { Equipment Finance } \\
\text { (incl. ALD Automotive) }\end{array}$ & France & 19143335 & 578771 \\
\hline 2. & $\begin{array}{l}\text { BNP Paribas Leasing } \\
\text { Solutions (incl. Arval) }\end{array}$ & France & 18256472 & 620784 \\
\hline 3. & VW Leasing GmbH & Germany & 15278733 & 609941 \\
\hline 4. & DLL International BV & Netherlands & 10400581 & 168606 \\
\hline 5. & Deutsche Leasing & Germany & 8437000 & 76140 \\
\hline 6. & UniCredit Leasing & Italy & 6732861 & 122234 \\
\hline 7. & Alphabet & Germany & 5973771 & 226708 \\
\hline 8. & Nordea Finance & Sweden & 5515485 & 221006 \\
\hline 9. & $\begin{array}{c}\text { Crédit Agricole } \\
\text { Leasing \& Factoring }\end{array}$ & France & 5173665 & 114216 \\
\hline 10. & DNB Finans & Norway & 4358419 & 172069 \\
\hline 11. & CM CIC BAIL & France & 4160679 & 112949 \\
\hline 12. & ING Lease & Netherlands & 3212475 & 37880 \\
\hline 13. & LeasePlan Corporation & Netherlands & 3156998 & 295153 \\
\hline 14. & $\begin{array}{l}\text { Siemens Financial } \\
\text { Services GmbH (SFS) }\end{array}$ & Germany & 2555382 & n.a. \\
\hline 15. & LBBW Leasing & Germany & 2472584 & 42101 \\
\hline
\end{tabular}

Source: Leaseurope

In the Czech Republic, according to the information provided by the Česká leasingová a finanční asociace ČLFA (Czech Leasing and Finance Association) (ČLFA 2019a), its members provided financing totaling almost CZK 164 billion for 2018, of which leasing of movable investments (machinery, equipment and vehicles) for businesses was CZK 51,1 billion (down by CZK 4,47 billion year on year). 
Even within the Czech Republic, the aforementioned trend showing the affiliation of leasing companies to either large financial groups or suppliers of funded subjects applies, as shown in Table 2:

Table 2 Ranking of ČLFA Member Companies by the Amount of Input Debt for Financing of All Commodities and for all Financial Products in 2018

\begin{tabular}{|c|c|c|}
\hline Rank & Company & $\begin{array}{l}\text { New business in } \\
2018 \text { (in M CZK) }\end{array}$ \\
\hline 1. & UniCredit Leasing CZ, a.s. & 16847,63 \\
\hline 2. & ČsOB Leasing, a.s. & 15860,66 \\
\hline 3. & ŠkoFIN s.r.o. & 15404,26 \\
\hline 4. & Home Credit, a.s. & 10651,32 \\
\hline 5. & Raiffeisen-Leasing, s.r.o. & 9978,44 \\
\hline 6. & SG Equipment Finance Czech Republic s.r.o. & 9862,22 \\
\hline 7. & Mercedes Benz Financial Services Česká republika s.r.o. & 8300,61 \\
\hline 8. & ESSOX, s.r.o. & 8166,10 \\
\hline 9. & s Autoleasing, a.s. & 5785,37 \\
\hline 10. & MONETA Auto, s.r.o. & 4356,66 \\
\hline 11. & LeasePlan Česká republika, s.r.o. & 4126,39 \\
\hline 12. & ALD Automotive s.r.o. & 4109,19 \\
\hline 13. & MONETA Leasing, s.r.o. & 3355,46 \\
\hline 14. & Erste Leasing, a.s. & 3260,85 \\
\hline 15. & ARVAL CZ s.r.o. & 2522,71 \\
\hline
\end{tabular}

Source: ČLFA

Due to the fact that most leasing companies belong to large financial groups and their financial statements are consolidated, these companies are also required to comply with regulatory requirements, currently including Basel III capital adequacy requirements. To some extent, leasing providers are in a similar position to their parent banks, although the risk status and the ways the risk - in particular credit risk - is managed, is fundamentally different for leasing companies. 


\section{Methodology and Data}

Information on the position of the leasing companies in relation to Basel III rules was largely drawn from the European Federation of Leasing Company Associations Leaseurope, which publishes this data on its official website (Leaseurope 2019). Its members are 45 member associations from 32 countries, representing over 1400 leasing companies and thus about 93\% of the leasing market in Europe. In addition, around 500 short-term rental companies are represented.

From the EU member states, Romania, Croatia, and Cyprus are missing in Leaseurope, while member countries include Morocco, Norway, Russia, Switzerland, Turkey, Tunisia, and Ukraine. The Czech Republic is represented by the Czech Leasing and Finance Association (ČLFA).

The official headquarters of Leaseurope is in Brussels, with Anne Valette serving as the CEO.

Leaseurope represents its members and promotes their interests in dealing with European and international institutions, informs and provides expertise, and, last but not least, maintains pan-European statistics on leasing and related financing. Leaseurope also works on some topics with the European federation of consumer credit providers Eurofinas - some associations (and thus some financial companies) are indeed members of both federations.

Nine of the largest leasing companies in the Czech Republic were selected for the comparison within the leasing market in the Czech Republic, based on the indicator "Ranking of CLFA member companies by the amount of input debt in financing all commodities and all financial products in 2018", published regularly in ČLFA statistics.

The Czech leasing market mainly consists of members of the above-mentioned Česká leasingová a finanční asociace ČLFA (Czech Leasing and Finance Association). This organization was founded in 1991 as the Association of Leasing Companies of the CSFR in former Czechoslovakia. "Currently, 42 companies are members of the Czech Leasing and Finance Association, which account for about $97 \%$ of all domestic leasing transactions, most of the non-bank loans for consumers and most of the factoring deals" (ČLFA 2019b).

Furthermore, data from publicly available sources, especially annual reports of selected leasing companies and banks, as available on the on-line version of the Czech Commercial Register, was used.

These datasets make it possible to achieve the objectives of this paper using methods of financial analysis, especially balance sheet ratios (assets and liabilities). For evaluation of the situation of leasing companies operating in the 
Czech Republic in terms of capital adequacy and preparedness for the intended new rules, two basic indicators were chosen: (i) the Equity / Balance sheet ratio and (ii) the Equity / Receivables ratio from the provided financing or from the business relations (depending on how the leasing company keeps them in its accounting). These indicators were chosen because of the availability of data and at the same time as the closest attainable approach to the capital adequacy ratio for Basel regulation. As a supplementary indicator, (iii) the ratio of Basic Capital to Balance Sheet Total can be mentioned.

\section{Results and Discussion}

\subsection{Leaseurope's Opinion on the New Regulation}

The document The impacts of Basel 3 on the European leasing industry - A Leaseurope research project by Deloitte describes the situation during the period when the earlier Basel II rules were in force:

"Basel 2 (current CRD) requirements for leasing:

- $\quad$ Under the standardised approach, risk-weights depend on the asset class of the counterparty and the leased asset is not recognised as mitigating risk.

- Under the IRBF approach, LGD varies between $35 \%$ and $40 \%$ depending on the national regulator.

- Under the IRBA approach, internal models allow a more accurate approach of the risk" (Fleuret N., Phaure H. for Deloitte 2012, p.6)

IRBF stands for the foundation internal ratings-based approach (the abbreviations F-IRB is also used in various documents), IRBA stands for the advanced internal ratings-based approach (also mentioned as A-IRB).

As stated by ČNB (2018, p. 112-114), "at the end of 2017, the Basel Committee on Banking Supervision (BCBS) introduced a package of proposals aimed at strengthening the risk capital framework Basel III. (...) All changes should be implemented by 1 January 2022 with the exception of the binding minimum level of risk weights from internal models, which is subject to a transition period ending on 1 January 2027" (translated by author).

Figure 1 shows some of the New Basel proposals affecting leasing in a short form, as stated in Leaseurope's document Prudential Treatment of Leasing (Leaseurope 2018b, detailed below): 
Figure 1 New Basel Proposals Affecting Leasing

\begin{tabular}{l} 
IRB-FOUNDATION \\
OVERCOLLATERALISATION - only considered 'secured' if collateral value \\
IRB-ADVANCED \\
minus a $40 \%$ haircut is larger than the outstanding loan value at default REVIEWED \\
\hline $\begin{array}{c}\text { REGULATORY LGD REVIEWED } \\
\text { LGD FLOORS NEW }\end{array}$ \\
$\begin{array}{c}\text { 45\% unsecured bank Corporates / } 40 \% \text { unsecured non-bank } \\
\text { Corporates / } 25 \% \text { secured on physical collateral }\end{array}$ \\
$\begin{array}{c}\text { OUTPUT FLOOR: capital requirements under the IRB Approaches cannot be lower } \\
\text { than } 72.5 \% \text { of what they would have been under the Standardised Approach NEW }\end{array}$ \\
\hline
\end{tabular}

Source: Leaseurope (2018b)

The leasing companies are protected by Leaseurope as they have to comply with the same stringent capital adequacy requirements as banks under the new Basel III rules. Therefore, in April 2018, an extensive document Leaseurope response to the European Commission consultation on the finalisation of Basel III (Leaseurope 2018a) was prepared. In the first part, Leaseurope emphasized that the demonstrated low risk of leasing, which is documented by the results of the Cologne University research (see below), is not recognised by the calculations for the current Capital Requirements Regulation framework. For all three regulatory credit risk approaches, capital requirements are much higher than the unexpected losses projected in downturn simulations.

Separate chapters dealt with the Standardised approach (with a requirement of a differentiated capital treatment for leasing and the proposal that exposures secured by durable goods should be recognised as collateral) and Internal Rating Based approaches, where Leaseurope, besides other things, urged the Commission not to exclude exposures to large and mid-sized corporates and exposures to banks and other financial institutions from using the A-IRB. In the last chapter, the proposed output floors based on the SA calculations were mentioned. If applied, the capital advantage of all the investments in the A-IRB approach (as made over the past years by many leasing companies) would be minimal. The next sub-chapter deals with operational risk.

At the end of the document, Leaseurope states:

"If Leaseurope's proposals in this response, both for standard and internal approaches, are not taken into account by the European Commission, leasing will be significantly hit by the new framework as the current LGD levels are very low compared to traditional unsecured lending products." (Leaseurope 2018a, p. 13)

Reference is also made here to another document, The Risk Profile of Leasing in Europe - The role of the leased asset (Leaseurope 2013a). The sample portfolio used in the study, prepared for Leaseurope by Deloitte France, included 
data from 17 major European leasing companies, covering their activities in 15 European markets during the period 2007-2011 (years covering the depths of the European economic crisis). Data for 3,3 million contracts, covering both equipment (64\%) and automotive (36\%) assets and including over 184.000 of defaulted contracts was used (Leaseurope 2013a).

"The key findings of the study are:

- $\quad$ Loss rates are lower for leases than for traditional lending.

$>$ Over $60 \%$ of lease defaults upgrade to healthy and have a zero loss.

$>$ Loss rates on the Corporate and Retail SME exposures of our portfolio were $11.1 \%$ and $19.6 \%$ respectively. This compares very favorably to the figures of the EBA's EUwide 2011 stress test where equivalent loss rates for Corporate and Retail SME lending were $31 \%$ and $36 \%$ respectively.

- Asset sale proceeds contribute significantly to the low net losses for leasing.

$>$ In $80 \%$ of defaults where the lease does not upgrade, the asset is sold.

$>$ Over $20 \%$ of these contracts (i.e. defaults that do not upgrade and where the asset is sold) have a zero loss.

$>$ At the portfolio level, asset sale proceeds account for $80.3 \%$ of total recoveries.

- Regulatory LGD requirements significantly overstate leasing losses.

$>$ The average loss simulated using a bootstrap technique is $23.15 \%$, with a stressed loss rate (99.9th percentile) of $24.2 \%$.

$>$ An extremely high discount factor (23\%) would need to be applied to leasing loss rates in order to reach the regulatory (IRB-Foundation) LGD of $40 \%$." (Leaseurope $2013 a$, p.2)

The next document Capital Requirements for Leasing: A Proposal Adjusting for Low Risk (University of Cologne for Leaseurope, 2017, cited in Leaseurope 2018a) and following Prudential Treatment of Leasing (Leaseurope 2018b) dealt with the Real unexpected loss for leasing. According to research, based on more than 2,4 million leasing contracts across 25 European countries, the unexpected loss for leasing is $1, \mathbf{1} \%$, while the regulatory capital requirements based on individual approaches (utilized models) require $\mathbf{8 , 3} \%$ for Standardized Approach, $\mathbf{5 , 8} \%$ for IRB-Foundation Approach and finally $\mathbf{5 , 3} \%$ equity for the most complex (and the most expensive to create and operate) IRBAdvanced Approach. 
- $\quad$ "In 10,000 simulations per year, leasing's realised losses (expected \& unexpected) were never higher than the regulatory capital requirements, which are designed to cover only unexpected losses.

- Standardised Approach does not allow the positive impact of leased assets to be taken into account.

- IRB Approach treats leasing the same as bank loans secured by physical assets, despite their different risk profile." (Leaseurope 2018b, p. 3)

Other issues mentioned in this document are some of the newly proposed Basel III limits and new rules that, if approved, would have a negative impact on leasing companies, without requiring such risk management requirements and real risk situation - according to Leaseurope and Deloitte. These are, in particular, the input parameter floors which penalize low risk forms of lending, excessively conservative prescribed haircuts (more leasing is considered 'unsecured'), benchmarking IRB Approaches to the Standardised Approach (which artificially limits the benefit of internal modelling), high estimated increase in capital requirements for European lessors under the IRB-A (11\% due to the output floor alone), and the inability to use the IRB-A Approach for banks and large corporates. (Leaseurope 2018b, p. 4)

Leaseuropes's suggestions are as follows:

a) "Introducing a specific risk weight for leasing exposures under the Standardised Approach would bring it more in line with the real risks, while also ensuring any output floor does not result in excessive limits on the IRB Approaches.

b) Haircut should be reduced for lease exposures, as if not adjusted leasing would require a regulatory LGD of $16 \%$.

c) A leasing specific regulatory LGD under the IRB-F Approach, different to "other physical assets", would ensure physical asset specialists like lessors are not penalised.

d) Any input floors should be calibrated at levels which do not artificially raise LGDs for low risk business models." (Leaseurope 2018b, p. 4)

Implicit Risk Weights for SME Leasing in Europe (Leaseurope 2013b, created for Leaseurope by Deloitte) looked into the issue more narrowly, from the SME (small and medium enterprises) perspective. This document, among other things, compared capital requirements according to Basel approaches to the internal study model, based on more than 1,5 million contracts of SMEs and 10 major European leasing companies, covering their activities in 10 European markets in the Five year period (2007-2011), covering the depths of the European economic 
crisis. The sample included more than 108000 of defaulted contracts. The Implicit Risk Weight (unexpected loss) of the internal model was 0,634\% (Monte Carlo simulation to estimate the 99,9 th percentile value of the total loss distribution (credit Value-at-Risk $=1,369 \%$ ), from which the expected loss (PD $x$ $\operatorname{LGD}=0,735 \%$ ) is subtracted in order to obtain the unexpected loss of $0,634 \%$ ). In contrast, there are capital requirements from 7\% (Standardized Approach) to $6 \%$ (IRB-Foundation Approach) or at best 4\% (IRB-Advanced Approach). Thus, in all cases, Basel requires leasing companies to hold several times more equity than would be necessary.

According to the same document, the situation for leasing financing looks similar in terms of default rates:

"The average one-year default rate on the sample portfolio is $2.64 \%$. This is very low when compared to equivalent default rates on the Retail SME portfolios of EU banks2. For instance, the sample portfolio's default rate for 2010 is $2.8 \%$ compared to the EBA's EU-wide rate of $4.5 \%$." (Leaseurope 2013b, p. 2)

Besides leasing companies themselves, the issue of capital adequacy in leasing companies was mentioned, for example, by Schmit et al. (2003) in preparing the first Basel Capital Adequacy Accord and the EU New Capital Adequacy Framework, as he stated: "Our results confirm that leasing is a low-risk activity and point to the need to review the Basel proposal in order to provide for better recognition of physical collaterals other than real estate" (Schmit et al. 2003 p. 34).

Hartmann-Wendels and Honal (2010) pointed out that in the case of leasing contracts, the actual LGD is in some cases negative, i.e. that the leasing company receives more than the amount of its contract receivable for the forfeited and sold object (e.g. car, truck, etc.). The coverage of credit risk using the subject of financing is also dealt with in more detail by Svítil (2011).

Salonen (2011) expects bank owned leasing companies to be required to hold equity of ca. $10-12 \%$ of total capital according to Basel III. This is the sum of all capital items, where the uncertainty is determined, among other things, by a countercyclical buffer setting in the expected range of 0 to $2 \%$.

According to Phaure from Deloitte (2013), capital requirements should be 10,5\% from 2020 onwards, again in the form of a summary of all items. Phaure expects, in connection with this, the need for capital increases for leasing companies.

\subsection{Capital Adequacy of Czech Leasing Companies}

For evaluation of the situation of leasing companies operating in the Czech Republic in terms of capital adequacy (represented by the requirements for the 
volume of equity) based on publicly available sources (i.e. mandatory financial statements and annual reports), a simplification has to be made.

As basic indicators, (i) the Equity / Balance sheet ratio and (ii) the Equity / Receivables ratio from the provided financing or from the business relations (depending on how the leasing company keeps them in accounting) can be used. As a supplementary indicator, (iii) the ratio of Basic Capital to Balance Sheet Total can be mentioned.

Selected indicators for the largest leasing companies are shown in Appendix 1, 2 and 3.

As shown in the table and graphs, most of the major leasing companies operating on the Czech market have no problem not only in meeting the current capital adequacy requirements, but also in meeting any increased Basel III rules. Even if the most pessimistic estimates of capital requirements of up to $12 \%$ (Salonen 2011 ), or $10.5 \%$ respectively (Phaure for Deloitte 2013) are used, only one leasing company (Raiffeisen-Leasing) would touch the highest limit for the most conservative Equity / Balance sheet total indicator (11,8\% in 2017) and two others would approach it (SG Equipment Finance and Mercedes Benz Financial Services). For the less conservative Equity / Receivables indicator, even Raiffeisen Leasing would meet the requirements with $13,6 \%$.

In the case of comparison with the more recent assumptions of Leaseurope, where the range is between $5,3 \%$ and $8,3 \%$, depending on the model used, none of the leasing companies under review would need to increase equity.

On the other hand, the extremely favorable economic situation of the Czech Republic in recent years has to be taken into account. This is, of course, reflected in the leasing companies' financial performance, both by increasing their new business volumes and by decreasing the number of default contracts / clients.

However, this current favorable situation may change and leasing companies can get into a much more difficult position within a few years (or even months), as was the case, for example, during the last financial crisis of 2008-2009.

Therefore, it is advisable to model such a situation, that is, to perform a type of stress testing and to estimate changes in capital requirements in case of adverse economic developments. Due to the limited granularity of available data, simplified stress tests were selected at a $\mathbf{5 \%}$ and $\mathbf{1 0} \%$ rate of a net loss of receivables. The net loss after the PD and LGD factors is taken into account, including the seizure and repression of leasing items:

- Stress test on the Equity / Balance Sheet indicator shows the situation of the impairment of receivables by $5 \%$ or $10 \%$ and cover of this entire loss by reducing equity. Thus, the balance sheet total 
will be reduced by the corresponding amount of assets (impairment of receivables) and equity. Then the updated Equity / Balance Sheet ratio is calculated.

- Stress Test on the Equity / Receivables indicator also shows a 5\% or $10 \%$ reduction in receivables and cover of this entire loss by reducing equity. The equity and debt indicators are therefore reduced by the corresponding amount. Then the updated Equity / Receivables ratio is calculated.

So these tests are much more pessimistic than Leaseurope's assumptions (see above). The results of these simplified stress tests for major leasing companies on the Czech market are shown in Appendix 4 and 5.

It follows that in the case of only a $5 \%$ loss of Equity / Balance Sheet indicator, Raiffeisen-Leasing (7,8\% for 2017 numbers) falls below the threshold foreseen by Salonen (2011) and Phaur (2013) and nears the limit set by Leaseurope (2018). Some other companies (UniCredit Leasing, ŠkoFIN, SG Equipment Finance, Mercedes Benz Financial Services) are at around 12\%. The Equity / Receivables indicator is again more favorable, but even here the relatively weakest capital position of Raiffeisen-Leasing is evident.

In the case of a more extreme stress test with a net loss of $10 \%$ of receivables, Raiffeisen-Leasing, as the relatively weakest of the monitored group of companies, manifests values $(3,4 \%$ for 2017 numbers) below the threshold foreseen by Leaseurope (2018) in both ratios. On the other hand, the view of the results of the parent company Raiffeisenbank in the Czech Republic for 2017 (according to the 2017 Annual Report of Raiffeisenbank; Raiffeisenbank 2018) shows that this bank has enough equity capital not only for its own needs (CZK 23,1 billion equity compared to the CZK 10,4 billion of total regulatory capital), but also to cover the needs of its subsidiary leasing company. Therefore, the relatively weaker capital position of Raiffeisen-Leasing is not a serious issue.

Also the results of the largest leasing company in the Czech Republic, UniCredit Leasing, are not optimal (10\% Stress test on Equity / Balance sheet total: 6,5\% for 2017 numbers), even though they fulfill the assumptions of Leaseurope (2018) for IRB-Advanced Approach, which is used within the Unicredit Group, as stated in UniCredit Bank's Annual Report 2017 (Unicredit Bank 2018).

Particular mention should be made of the situation of Mercedes Benz Financial Services and sAutoleasing, whose asset structure is somewhat atypical compared to other leasing companies, with trade receivables shares of only about $26 \%$ and $22 \%$, respectively, of the assets of these companies in 2017 . The largest share of assets (in both cases around 57\%) consisted of tangible fixed assets. For this reason, the differences between Equity / Balance sheet and Equity / Receivables 
differ considerably for Mercedes Benz Financial Services and sAutoleasing. For the other monitored leasing companies, receivables have a larger share of assets (in the case of UniCredit Leasing even almost 93\%) and the differences between the Equity / Balance sheet and Equity / Receivables ratios are significantly smaller. See Table 4 for details.

It should also be noted that this contribution is devoted solely to the factual fulfillment of the capital requirements imposed on the leasing company and not the associated costs. Such research could be of interest in the future, but it would probably require access to data that is not commonly published (e.g. to assess the cost of equity and equity of individual companies).

\section{Conclusions}

In its first part, this article summarizes findings from available sources, concerning the risk taken by the leasing companies on capital adequacy. These sources show that the risk associated with the provision of liabilities through leasing is significantly lower than the risk calculated by the capital adequacy calculation for Basel III rules. The same conclusion was reached by other authors, independent of Leaseurope and leasing companies in general.

For this reason, the Leaseurope has a negative view of the fact that under modified Basel III (so-called Basel IV) regulation, the same capital adequacy rules should apply to leasing companies as to banks. The Leaseurope answers the (i) first question from the Introduction of this article, whether new regulation should be adopted, by preparing some concrete proposals for changes in the rules so that the regulation better corresponds to the actual risks taken.

The second part of this work shows that large leasing companies in the Czech Republic are usually equipped with a sufficient amount of equity, both to cover capital adequacy requirements in the current situation and in the event of a significant loss of net receivables. Only a few companies could, in the event of a deeper crisis (expressed in the modelled case by a very pessimistic estimate of a $10 \%$ loss of net receivable), reach the thresholds and just one company would probably not be able to meet these requirements without additional equity

\section{References}

\section{Annual reports 2017 of selected leasing companies:}

ČSOB Leasing (2018). Retrieved from: https://or.justice.cz/ias/ui/ vypis-sl-detail?dokument $=53251887 \&$ subjektId $=124976 \&$ spis $=$ 76009

ESSOX (2018). Retrieved from: https://or.justice.cz/ias/ui/vypis-sldetail ?dokument $=53528532$ \&subjektId $=709228 \&$ spis $=424824$ 
Mercedes-Benz Financial Services (2018). Retrieved from: https://or.justice.cz/ias/ui/vypis-sl-

detail ?dokument $=53935046 \&$ subjektId $=472665 \&$ spis $=127742$

MONETA Auto (2018). Retrieved from: https://or.justice.cz/ias/ui/ vypis-sl-detail?dokument $=56523407 \&$ subjektId $=78493 \&$ spis $=$ 248358

Raiffeisen - Leasing (2018). Retrieved from: https://or.justice.cz/ ias/ui/vypis-sl-detail?dokument $=53548913 \&$ subjektId $=671627 \&$ spis $=118285$

s Autoleasing (2018). Retrieved from: https://or.justice.cz/ias/ui/ vypis-sl-detail ?dokument $=53424314 \&$ subjektId $=76121 \&$ spis $=80$ 377

SG Equipment Finance Czech Republic (2018). Retrieved from: https://or.justice.cz/ias/ui/vypis-sl-detail?dokument $=53379675 \&$ subjektId $=158110 \&$ spis $=130897$

ŠkoFIN (2018). Retrieved from: https://or.justice.cz/ias/ui/vypis-sldetail ?dokument $=53671227 \&$ subjektId $=710387 \&$ spis $=101608$

UniCredit Leasing CZ (2018). Retrieved from: https://or.justice.cz/ ias/ui/vypis-sl-detail?dokument $=52783816 \&$ subjektId $=68377$ \&spis $=73360$

\section{Annual reports 2017 of selected banks:}

Raiffeisenbank (2018). Retrieved from: https://or.justice.cz/ias/ui/ vypis-sl-detail?dokument $=55049297 \&$ subjektId $=445917 \&$ spis $=$ 74749

Unicredit Bank (2018). Retrieved from: https://or.justice.cz/ias/ui/ vypis-sl-detail dokument $=55061306 \&$ subjektId $=47976 \&$ spis $=$ 76109

ČLFA (2019a). Zpráva o stavu a vývoji nebankovního leasingového, úvěrového a factoringového trhu $v \check{C} R v$ roce 2018. Retrieved from: https://www.clfa.cz/data/dokumenty/830-2018zprava.doc

ČLFA (2019b). Kdo jsme. Retrieved from: https://www.clfa.cz/o-nas/kdojsme 
ČNB (2018). Zpráva o finanční stabilitě 2017/2018. Retrieved from: https://www.cnb.cz/cs/financni-stabilita/zpravy-fs/zprava-o-financnistabilite-2017-2018/index.html

Fleuret N. and Phaure H. for Deloitte (2012). The impacts of Basel 3 on the European leasing industry - A Leaseurope research project. Leaseurope Annual Convention Presentation 2012. Retrieved from: http://www.leasing.org.pl/files/uploaded/Cannes2012/3.\%20Fleuret.pdf

Hartmann-Wendels, T. and Honal, M. (2010). Do economic downturns have an impact on the loss given default of mobile lease contracts? An empirical study for the german leasing market. Kredit und Kapital, 43, pp. 65-96.

Leaseurope (2013a). The Risk Profile of Leasing in Europe - The role of the leased asset. Retreived from: http://www.leaseurope.org/uploads/ documents/Basel\%203/Risk\%20Profile\%20of\%20Leasing\%20$\% 20$ Key\%20Findings.pdf

Leaseurope (2013b). Implicit Risk Weights for SME Leasing in Europe. Retreived from: http://www.leaseurope.org/uploads/documents/Basel $\% 203 /$ Implicit\%20Risk\%20Weights\%20for\%20SME\%20Leasing $\% 20 i n \% 2$ 0Europe $\% 20-\% 20$ Key\%20Findings.pdf

Leaseurope (2018a). Leaseurope response to the European Commission consultation on the finalisation of Basel III. Retreived from: http://www.leaseurope.org/uploads/documents/PSC/pp180412_LEA_Bas el\%20IV.pdf

Leaseurope (2018b). Prudential Treament of Leasing. Retreived from: https://nvl-lease.nl/wp-content/uploads/2018/11/Leaseurope-LeafletPrudential-Treament-of-Leasing-Proposal.pdf

Leaseurope (2019). Leaseurope Key Facts and Figures 2017. Retrieved from: http://http://www.leaseurope.org/uploads/documents/Leaseurope FF_17_PRINT.pdf.

Phaure, H. for Deloitte (2013). Basel III Regulation and effect on leasing market. Working paper presented at Eurolease forum 2013 Milan.

Salonen, J.M.S. (2011). Basel III potential impacts to bank owned leasing company foundation and strategy. Retrieved from: http://www.leaseurope.org/uploads/documents/events/seminar_for_lesso rs/2011/Jukka\%20Salonen.pdf 
Schmit, M., Degouys, C., Delzelle, D., Stuyck, J. and Wautelet, F. (2003). Credit risk in the leasing business - a case study of low probability of default. Retrieved from: https://pdfs.semanticscholar.org/c9cf/e83252 $673341 \mathrm{f} 6 \mathrm{fb} 121213 \mathrm{fba} 8 \mathrm{c} 83 \mathrm{dbe2eac}$.pdf?_ga $=2.261124363 .721889384 .1$ $556884783-770817054.1556884783$

Svítil, M. (2011). Řízení finančního rizika při financování investic leasingem. Doctoral thesis. Brno: Ekonomicko-správní fakulta MU.

Svítil, M. (2019). Leasing companies in Czech Republic from the perspective of Basel III regulation. In: European Financial systems 2019. Proceedings of the International scientific conference European Financial systems 2019, Brno. ISBN 978-80-210-9337-9 resp. ISBN 978-80-2109338-6 (online). 


\section{Appendices}

Appendix 1 Basic Indicators of Capital Adequacy of Leasing Companies in the Czech Republic

\begin{tabular}{|c|c|c|c|c|c|c|c|c|c|c|c|c|c|c|c|c|c|c|}
\hline \multirow{2}{*}{$\begin{array}{l}\text { Leasing } \\
\text { company }\end{array}$} & \multicolumn{2}{|c|}{$\begin{array}{c}\text { UniCredit } \\
\text { Leasing CZ, } \\
\text { a.s. } \\
\end{array}$} & \multicolumn{2}{|c|}{$\begin{array}{c}\text { ČsOB Leasing, } \\
\text { a.s. }\end{array}$} & \multicolumn{2}{|c|}{ ŠkoFIN s.r.o. } & \multicolumn{2}{|c|}{$\begin{array}{c}\text { Raiffeisen- } \\
\text { Leasing, s.r.o. }\end{array}$} & \multicolumn{2}{|c|}{$\begin{array}{l}\text { SG Equipment } \\
\text { Finance Czech } \\
\text { Republic s.r.o. }\end{array}$} & \multicolumn{2}{|c|}{$\begin{array}{c}\text { Mercedes Benz } \\
\text { Financial } \\
\text { Services s.r.o. } \\
\end{array}$} & \multicolumn{2}{|c|}{ ESSOX, s.r.o. } & \multicolumn{2}{|c|}{$\begin{array}{c}\text { s Autoleasing, } \\
\text { a.s. }\end{array}$} & \multicolumn{2}{|c|}{$\begin{array}{l}\text { MONETA } \\
\text { Auto, s.r.o. }\end{array}$} \\
\hline & 2017 & 2016 & 2017 & 2016 & 2017 & 2016 & 2017 & 2016 & 2017 & 2016 & 2017 & 2016 & 2017 & 2016 & 2017 & 2016 & 2017 & 2016 \\
\hline $\begin{array}{l}\text { Share } \\
\text { capital }\end{array}$ & 981 & 981 & 3050 & 3050 & 865 & 865 & 450 & 450 & 146 & 146 & 115 & 115 & 2288 & 2288 & 500 & 500 & 1200 & 1200 \\
\hline Equity & 5337 & 5257 & 8882 & 7623 & 6316 & 5900 & 1932 & 1695 & 4097 & 3779 & 3146 & 2491 & 3509 & 3596 & 2122 & 2020 & 1449 & 1242 \\
\hline Receivables & 32552 & 28703 & 23445 & 21007 & 28059 & 26770 & 14250 & 11503 & 12294 & 12412 & 5517 & 4677 & 9235 & 7602 & 2485 & 2245 & 4337 & 3503 \\
\hline $\begin{array}{l}\text { Balance } \\
\text { sheet total }\end{array}$ & 35140 & 31022 & 46151 & 41066 & 42037 & 39383 & 16367 & 13235 & 30120 & 29642 & 21482 & 19964 & 13111 & 11661 & 11273 & 10035 & 7434 & 6216 \\
\hline $\begin{array}{l}\text { Equity / } \\
\text { Balance } \\
\text { sheet }\end{array}$ & $15,2 \%$ & $16,9 \%$ & $19,2 \%$ & $18,6 \%$ & $15,0 \%$ & $15,0 \%$ & $11,8 \%$ & $12,8 \%$ & $13,6 \%$ & $12,7 \%$ & $14,6 \%$ & $12,5 \%$ & $26,8 \%$ & $30,8 \%$ & $18,8 \%$ & $20,1 \%$ & $19,5 \%$ & $20,0 \%$ \\
\hline $\begin{array}{l}\text { Equity / } \\
\text { Receivables }\end{array}$ & $16,4 \%$ & $18,3 \%$ & $37,9 \%$ & $36,3 \%$ & $22,5 \%$ & $22,0 \%$ & $13,6 \%$ & $14,7 \%$ & $33,3 \%$ & $30,4 \%$ & $57,0 \%$ & $53,3 \%$ & $38,0 \%$ & $47,3 \%$ & $85,4 \%$ & $90,0 \%$ & $33,4 \%$ & $35,5 \%$ \\
\hline $\begin{array}{l}\text { Share } \\
\text { capital / } \\
\text { Balance } \\
\text { sheet }\end{array}$ & $2,8 \%$ & $3,2 \%$ & $6,6 \%$ & $7,4 \%$ & $2,1 \%$ & $2,2 \%$ & $2,7 \%$ & $3,4 \%$ & $0,5 \%$ & $0,5 \%$ & $0,5 \%$ & $0,6 \%$ & $17,5 \%$ & $19,6 \%$ & $4,4 \%$ & $5,0 \%$ & $16,1 \%$ & $19,3 \%$ \\
\hline
\end{tabular}

Source: Author based on Annual Reports of the mentioned leasing companies 
Appendix 2 Capital Volumes of Leasing Companies in the Czech Republic

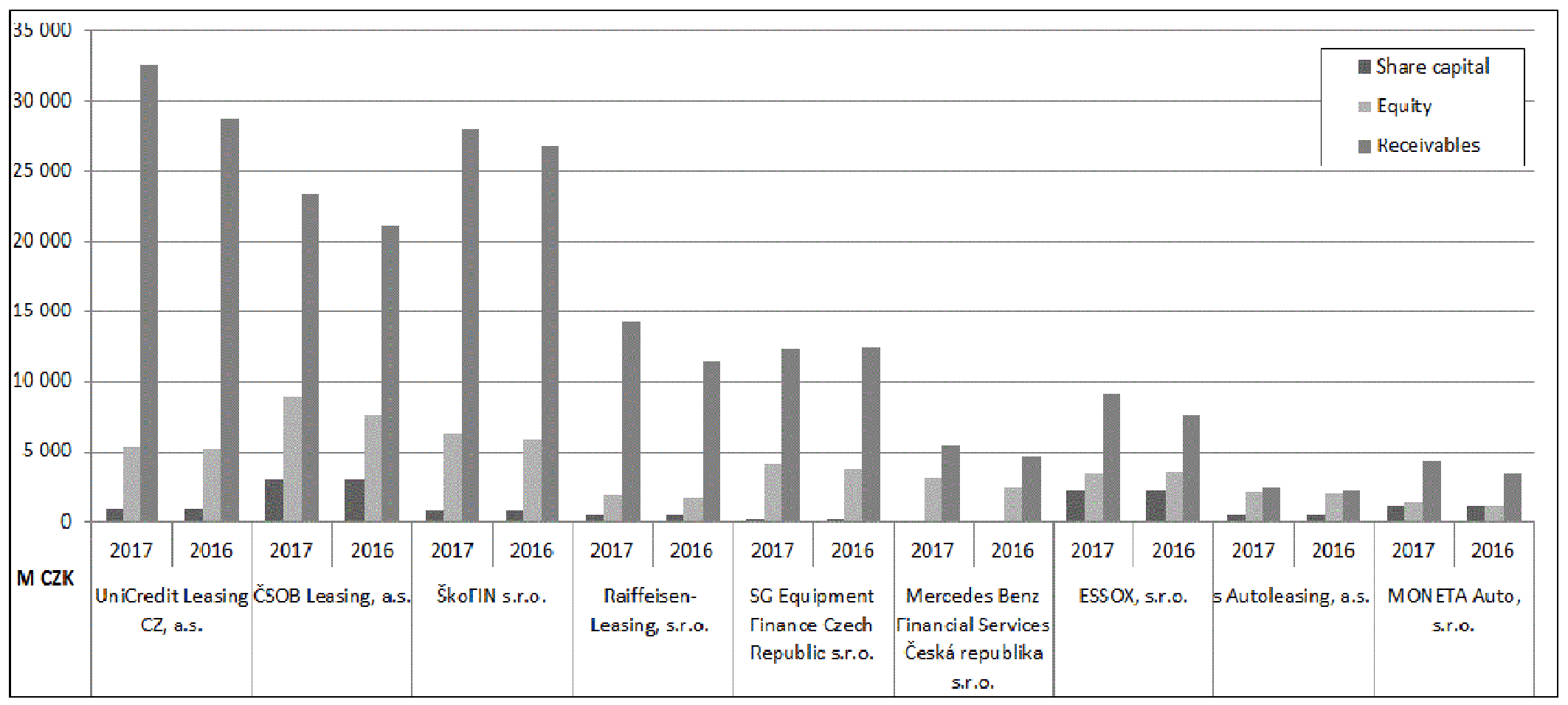

Source: Author based on Annual Reports of the mentioned leasing companies 
Appendix 3 Capital Adequacy Ratios of Leasing companies in the Czech Republic

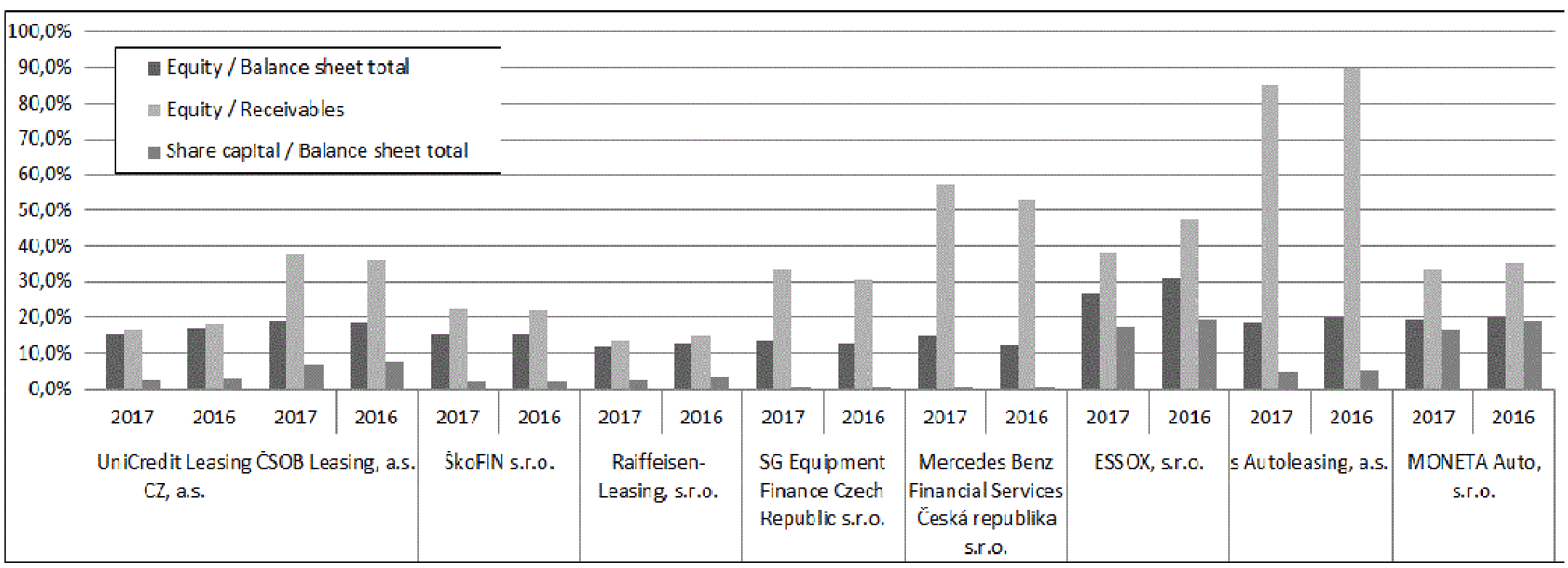

Source: Author based on Annual Reports of the mentioned leasing companies 
Appendix 4 Simplified Stress Tests of Capital Adequacy of Leasing Companies in the Czech Republic (in \%)

\begin{tabular}{|c|c|c|c|c|c|c|c|c|c|c|c|c|c|c|c|c|c|c|}
\hline \multirow{2}{*}{$\begin{array}{c}\begin{array}{c}\text { Leasing } \\
\text { company }\end{array} \\
\text { in CZK millions }\end{array}$} & \multicolumn{2}{|c|}{$\begin{array}{l}\text { UniCredit } \\
\text { Leasing CZ, } \\
\text { a.s. }\end{array}$} & \multicolumn{2}{|c|}{$\begin{array}{c}\text { ČsoB } \\
\text { Leasing, a.s. }\end{array}$} & \multicolumn{2}{|c|}{ ŠkoFIN s.r.o. } & \multicolumn{2}{|c|}{$\begin{array}{l}\text { Raiffeisen- } \\
\text { Leasing, } \\
\text { s.r.o. }\end{array}$} & \multicolumn{2}{|c|}{$\begin{array}{l}\text { SG Equipment } \\
\text { Finance Czech } \\
\text { Republic s.r.o. }\end{array}$} & \multicolumn{2}{|c|}{$\begin{array}{l}\text { Mercedes } \\
\text { Benz Financial } \\
\text { Services s.r.o. }\end{array}$} & \multicolumn{2}{|c|}{ ESSOX, s.r.o. } & \multicolumn{2}{|c|}{$\begin{array}{l}\text { s Autoleasing, } \\
\text { a.s. }\end{array}$} & \multicolumn{2}{|c|}{$\begin{array}{l}\text { MONETA Auto, } \\
\text { s.r.o. }\end{array}$} \\
\hline & 2017 & 2016 & 2017 & 2016 & 2017 & 2016 & 2017 & 2016 & 2017 & 2016 & 2017 & 2016 & 2017 & 2016 & 2017 & 2016 & 2017 & 2016 \\
\hline $\begin{array}{c}\text { Equity / Balance } \\
\text { sheet total: } \\
\text { Stress test } 5 \%\end{array}$ & 11,1 & 12,9 & 17,1 & 16,4 & 12,1 & 12,0 & 7,8 & 8,8 & 11,8 & 10,9 & 13,5 & 11,4 & 24,1 & 28,5 & 17,9 & 19,2 & 17,1 & 17,7 \\
\hline $\begin{array}{c}\text { Equity / } \\
\text { Receivables: } \\
\text { Stress test 5\% }\end{array}$ & 12,0 & 14,0 & 34,6 & 32,9 & 18,4 & 17,9 & 9,0 & 10,2 & 29,8 & 26,8 & 54,8 & 50,8 & 34,7 & 44,5 & 84,6 & 89,5 & 29,9 & 32,1 \\
\hline $\begin{array}{l}\text { Equity / Balance } \\
\text { sheet total: } \\
\text { Stress test } 10 \%\end{array}$ & 6,5 & 8,5 & 14,9 & 14,2 & 8,9 & 8,8 & 3,4 & 4,5 & 9,9 & 8,9 & 12,4 & 10,4 & 21,2 & 26,0 & 17,0 & $18,3 \%$ & 14,5 & 15,2 \\
\hline $\begin{array}{c}\text { Equity / } \\
\text { Receivables: } \\
\text { Stress test 10\% }\end{array}$ & 7,1 & 9,2 & 31,0 & 29,2 & 13,9 & 13,4 & 4,0 & 5,3 & 25,9 & 22,7 & 52,2 & 48,1 & 31,1 & 41,4 & 83,8 & 88,9 & 26,0 & 28,3 \\
\hline
\end{tabular}

Source: Author's calculations 
Appendix 5 Simplified Stress Tests of Capital Adequacy of Leasing Companies in the Czech Republic

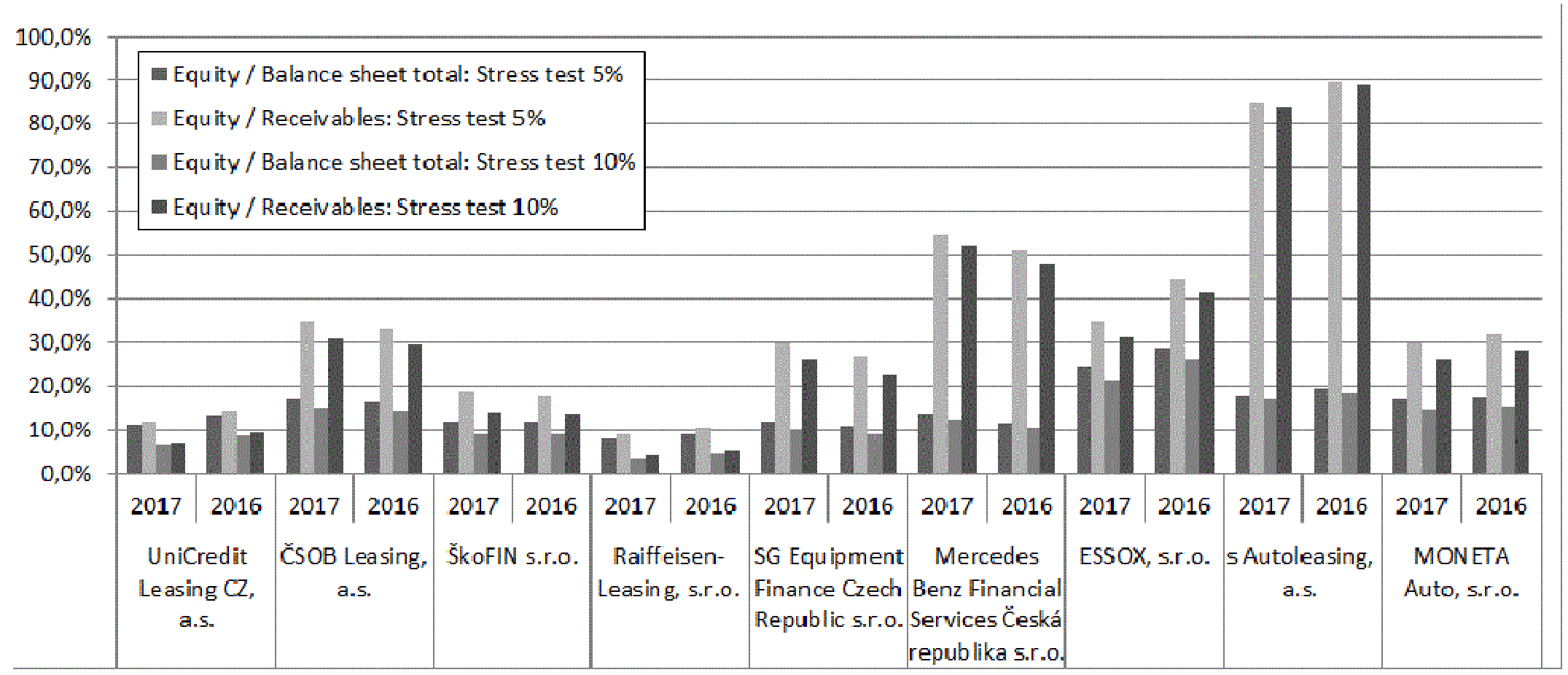

Source: Based on author's calculations 